Círculo de Lingüística Aplicada a la Comunicación

ISSN: $1576-4737$

\title{
Rhetorical Analysis of a Discourse Model in the Business World: Elevator Pitch
}

Javier de Santiago-Guervós ${ }^{1}$

Recibido: 14 de noviembre de 2019 / 24 de noviembre de 2019

\begin{abstract}
This paper proposes an analytical model for entrepreneurial pitches based on the five canons of rhetoric (i.e. invention, arrangement, style, memory and delivery), through the $d e$ construction of the text from the discursive act itself (as conceived in the invention phase) to its actual production (i.e. delivery). The questions this methodology attempts to answer are why the pitch may be persuasive and how that persuasion is achieved by analyzing its discursive and linguistic characteristics; what ethical, rational or emotional arguments are appealed to; who the potential audience is, and what other multimodal resources are used to support the persuasive force of the text. In order to answer these questions, two pitches in Spanish are deconstructed and conclusions regarding their efficacy are drawn.
\end{abstract}

Key words: Persuasion; rhetoric; discourse analysis.

\section{[es] Análisis retórico de un modelo de discurso en el ámbito comercial: Elevator Pitch}

Resumen. En este trabajo se propone un modelo analítico para un tipo de discurso comercial (Elevator Pitch) basado en los cinco cánones de la retórica clásica (inventio, dispositio, elocutio, memoria y actio). Partiendo de dos discursos opuestos desde el punto de vista de su eficacia, se pretende deconstruir el texto para comprender las razones del logro persuasivo (o de su fracaso) analizando sus características discursivas y lingüísticas desde el mismo momento de la planificación (estudio del destinatario, argumentos, etc.) hasta la puesta en escena pasando por una selección léxica (elocutio) perfectamente estudiada que pretende estimular marcos cognitivos de interpretación que apoyan la propia argumentación en favor de la persuasión del interlocutor.

Palabras clave: Persuasión; retórica; análisis del discurso.

Contents. 1. Introduction. 2. Methodology. 3. Corpus. 4. Analysis and results. 4.1. Inventio. 4.2. Dispositio. 4.3. Elocutio. 4.4. Actio. 5. A negative model of discourse. 6. Conclusion. References.

Cómo citar: Santiago-Guervós, J. de (2019). Rhetorical Analysis of a Discourse Model in the Business World: Elevator Pitch. In: Fernández-Ulloa, T. (ed.) The Rhetoric of Persuasion. Talking to Our Emotions. Círculo de Lingüística Aplicada a la Comunicación 80, pp. 7-16, https://dx.doi.org/10.5209/clac.66597.

${ }^{1}$ University of Salamanca (Spain). Email: jguervos@usal.es 


\section{Introduction}

The analysis of discourse, whether it be of a persuasive intention or of any other kind, means performing a sort of deconstruction in order to get to the original idea the author had in mind in its conception. The analysis begins by studying the actual discursive act (oral or written), and its staging, and from that point of reference, it moves backwards. Starting with the effects that any persuasive discourse has on the receiver, 'why' and 'how' questions can be posed: why is this discourse able to persuade us and how is that accomplished? What words does the author use and what effect do they have on us? What arguments are used and in what order? What ideas are being transmitted and who is the discourse directed towards? The production process of the text is enveloped and directly affected by the process of reception. It is a work of pure empathy (Pujante, 1999: 33).

With all likelihood, from the time humankind acquired the ability to communicate, people have been using the same patterns to produce discourse. It is an intuitive order (Pujante, 1999: 135). Every minimally informative communicative act (a class, designing a lesson for a book, an examination, a speech, a presentation) follows the same outline already defined by classical rhetoric (Fernández, 2006: 20).

Ultimately, the concept of any communicative act involves what is going to be said, to whom, and how the discourse is going to be organized and framed in order to proceed with the real execution of the plan.

\section{Methodology}

Certainly, the act of creating a persuasive discourse consists of a series of components that have remained invariable over the centuries. There has been no great change in this area since the time of classical rhetoric, which addressed discourse by making a taxonomy of the elements involved in its elaboration. This classical taxonomy made use of the current patterns in the creation of discourse (the rhetoric of systematizing common meaning with respect to communication, Albadalejo, 2014: 23).

The first step is to analyze the basic ingredients of the discourse, logos, ethos, and pathos, that is, the words, the character or presence of the orator, and the emotions or rationality with which the speech is received. At the core of these three fundamental elements is the structure of the discourse, the partes artis, which affects each one of them within the basic elements of communication. Thus, the sender begins with the inventio, which, broadly speaking, has to do with what we are going to say, to whom we are addressing it (receiver), with which purpose it is intended, what type of arguments are to be used, and what format is to be employed. In other words, with the way the discourse will be configured (description, narration and so forth), the type of genre chosen, and the style used.

In the inventio, the discursive matter is gathered. In the dispositio, all this material is ordered and structured in the most appropriate way to achieve the intended goals. For this reason, it is common use to pose the problem at the beginning and analyze it step by step or to place the strongest arguments at the end to reinforce the argumentation. In the elocutio, the words and the syntactic structures that channel the arguments are chosen. This is the code. The lexical selection is crucial because the choice of one term or another has an influence on the receiver's response since it stimulates different cognitive frameworks. Finally, there is memoria, if the discourse must be memorized, and actio, staging 
the action, where ethos is exalted as a fundamental communicative instrument when the discourse is spoken. The sender offers an image of himself that transmits an enormous amount of information. But the staging is not only the ethos, it is also the channel (television, newspaper...) or the context (the place where the discourse is delivered). Both are sources of communicative effect as well. The aim is often to submit the receiver to the authority of a court of justice, a forum, a parliament, a palace, and so on. (Santiago-Guervós, 2005, 2008). The discourse seeks, basically, an emotional or a rational response, relying on the knowledge of human psychology.

By considering the aim of the discourse and its audience, a selection process of the different pieces of the puzzle that comprise the discourse is performed: textual selection, argumentative selection, lexical, syntactic, and morphological selection, ordering the elements that make up the discourse... In a nutshell, it creates an integrated linguistic meaning in a format that, once transmitted is processed in a cognitive framework that can re-elaborate the meaning to trigger inferences via the peripherical route (emotional inference: pathos) or the central route (rational inferences: logos).

Thus, ethos, pathos and logos, inventio, dispositio, elocutio, memoria and actio, and sender, receiver, channel, code and context are, from our point of view, the basic components that shape communication and through which communication must be understood. Classical rhetoric already conceived all these elements, which are as valid as ever, showing, among other things, that certain psychological and communicative characteristics of human beings have not changed much over the last 2500 years.

In this way, and following this outlay, we will proceed with an analysis of the discourses we are going to work with.

\section{Corpus}

The work presented next stems from two texts extracted from a Spanish television program aimed at an audience of entrepreneurs called Tu oportunidad (Your opportunity). We assume that the type of discourse is quite homogeneous, given that in a short time the candidates must illustrate the virtues of a specific product in order to convince a group of investors to finance and support them. This type of discourse is called the Elevator Pitch. The discursive scheme is clear; the structure of this type of discourse is similar, probably predefined by the mechanics of the television program: first, the presentation, followed by the purpose, exposition and defense of the product. The candidates execute these steps in a surprisingly irregular way, even though the program almost certainly instructed them in how they should organize their argumentation. Information disseminated on the internet and manuals on sales speech (Carnegie, 1994) can be summarized as follows:

It is necessary to know the product, sell it with passion and make the customer feel like the most important person in the world; establish a good relationship with them; understand their worries; be sensitive to their needs; speak with the customer; make them feel comfortable; aggregate value to human beings; and definitely be courteous (Brown, \& Levinson, S., 1987; Lakoff, 1973). Selling is a solution to a problem; the customer wants to know they are going to win; show the benefits.

From the analysis of these two elevator pitches, we will see how argumentation and language choice seek to provoke emotions, why they sway people, what universal responses they are looking for, what they imply, which cognitive framework they try to stimulate among others. The analysis examines the arguments in these terms: what, how and for what reason? 
In short, this commercial discourse moves through parameters similar to those that move political discourse and advertising discourse as canonical persuasive discourses.

Thus, according to Greenwald (1968) people compare the new information that they receive with other existing information which they remember, as well as with the feelings that have been linked to those memories and with biographical experiences. When a word is heard, its frame is activated in the brain through a process that gives access to terms close to those with which it is associated, to an image or to another type of knowledge. Each individual, according to their knowledge, experiences and socialization, interprets the terms to which meanings, connotations and diverse emotions are attached, and then responds. Indeed, we do not see things as they are, we see things as we are. Thus, when making a decision we do not rely so much on the rational analysis of benefits and harms as on the affective memories we have of other decisions previously taken. These are packages of knowledge that ultimately refer to the broader concept of worldview (Lakoff 1996, 2004).

Emotions, therefore, can have a personal component, related to our past experiences, to our socialization, but they also have a universal component, product of the signs, perceptions and behaviors that we share as a species (SantiagoGuervós, 2005), which makes it easier to foresee the emotional reactions of the audience, because, as Max Weber (1996) pointed out, power is nothing more than the capacity to predict with maximum accuracy the behavior of others. If we foresee how the information is processed by the recipient, we will know where we will have to stimulate so that it responds adequately to our interests. The communication professional knows the biology of human behaviour (EibleEibesfeldt, 1993), the uncertainty in which the human being lives, his gregarious need to be accepted by his environment in order not to be isolated and vulnerable; he knows the need to live in a predictable world in order to avoid uncertainty, fear, and the enormous consequences that these behaviours have on communication: the need to be reciprocal so as not to fall into cognitive dissonance and be rejected by the group; submission to authority and a long etcetera of universal behaviors that add to social experience and beat below communications, but are the target to which they aim to find the appropriate response to persuasive discourse (Escandell, et al. 2020).

Thus, to test the potential effectiveness of the Elevator Pitch, two quite different models of discourse will be analyzed using the Rhetorical Discourse Analysis in conjunction with the framework explained above as our starting point, an unpublished analysis for this type of discourse

\section{Analysis and Results}

In the first elevator pitch (31 October 2013, www.youtube.com/watch?v=xp333yNQCAE), the candidate makes a presentation to the potential investors about ByHours.com, the first platform that allows the user to book hotels on an hourly basis. To analyze this 8 minute-24 second discourse that includes a follow-up dialogue, we must take an inverse path, that is, undo in order to understand, deconstruct in order to complete the puzzle with the pieces pulled out of the discourse once they are understood. We will thus follow the rhetorical scheme explained at the beginning. 


\subsection{Inventio}

In the inventio, we plan the discourse (Laborda, 1996, 2014). The receiver of the message, in this case, the receivers, are business people, entrepreneurs, investors and specialists. Therefore, a total lack of attention in terms of language usage, that is, abundant use of anglicisms and technicisms, is to be expected. But the opposite was actually the case. In fact, technical language that shows knowledge and authority can be used, as well as more colloquial speech, as a technique for emotional proximity.

There is no possibility of selecting context because it is given by the program. The context is a peculiar one and the discourse is taken over by it.

The channel is direct, face-to-face. The aim of the discourse is to get financing, and, for this reason, there must be appropriate argumentation, which in this case, is based on offering a product that solves a problem and benefits the consumer and the businessperson. An appeal must be made to authority, courtesy, reciprocity, etc.

The argument for courtesy runs throughout the entire discourse. It is not expressed with any special vocabulary. The entire product is made for the benefit of customers, who pays to use it, as opposed to other kinds of hotel booking where they pay for what they do not use. It is an argument of courtesy that expects an answer of reciprocity from customers. The company is thinking about them, their savings, their comfort. It wants to make their life easier and they respond to it. It is the argument that makes customers be convinced and the one that can be used by the investors to sell the product themselves.

\subsection{Dispositio}

The structure of the discourse is imposed by the program, but it should follow a logical structure, according completely to rhetorical standards.

1.- The speakers introduce themselves, say their names, job titled and what they want. There is no captatio benevolentiae.

2.- The objective is stated: "We are looking for 300,000 euros at $8 \%$."

3.- They introduce the product and the benefits for the user: "Byhours is the FIRST on-line platform that allows the customer to decide the time of arrival and the time of departure, and how it will be booked."

4.- The questions lead to answers that describe the virtues of the product, which is worth the cost.

\subsection{Elocutio}

In the elocutio, the lexicon and syntax that support the argumentation are chosen. Arguments of authority, quantity, novelty and so on are backed by an appropriate choice of words and syntactic structures:

- The use of the informal "you" form, "tú", is used to facilitate familiarity and proximity. It seeks to reduce social distance. On the other hand, it matches with the informal, youngish and hip attire of the entrepreneur. Their presence, their way of expressing themselves, goes perfectly well with the type of person they represent and with the image they want to project. The entrepreneurs are young, welleducated and informal, but also intelligent and witty.

- At the same time, there are the formal speech patterns, technicisms, business jargon (the operating procedure, the tool, the package of hours, web page, product, financially sound investors, final customer, market, consumer, brand, industry, investors...) and anglicisms like dominant brand, Partners, "b2b" (business to business), look and feel, players, CEO, Byhours, on-line, OTAS (online travel 
agencies), upside... The use of technicisms and business jargon presents the entrepreneur as belonging to a special business world in which they feel themselves at ease and that makes them feel self-confident. They speak the same language and that is a plus.

The terms chosen are completely positive, magnifying the product:

Currently we have more than 400 hotels directly under contract (hyperbole, amplification, focusing the buildup) among which we are talking about the top chains in the country and not just this country, but they are also part of large hotel groups at the international level (authority). The leading travel group in Europe.

Large "OTAs" already sell online hourly packages. The leading online travel company in all of Europe on their main webpage already has a section of hourly packages of hotel sales, but the operational side, the tool, is all ours (the big ones operate with our tool!). We are providing a tool to all the important players in the industry so they can reach the final customer.

-Totally scalable model

We have very financially sound investors

a) In many cases, these lexical choices reinforce the argument of authority, which leads to a herd response: if the best endorse the product, we should do it too: "the top chains in the country and not just the country, but they are also part of large hotel groups at the international level (authority). The leading travel group in Europe. Large "OTAs" online already sell the hourly packages. The leading online travel company in all of Europe on their main webpage already has a section of hourly packages of hotel sales, but the operational side, the tool, is all ours (the big ones operate with our tool!). We are providing a tool to all the important players in the industry so they can reach the final customer, we have very financially sound investors, a patent in the USA because there is no similar model at the international level.... Quite definitely, the company is in contact with representatives of successful businesses, which is a magnet for more quality players: everyone wants to be with the strongest, with the best, with the winners. It is the bandwagon effect. We are the first...,

b) Argument of quantity: in line with the previous argument: more than 400 hotels contracted directly; from 114 transactions to 3000. An argument used habitually in politics and advertising to pull the foot-draggers into the majority.

c) Argument of newness: The market changes, new product, an argument that stimulates a very specific cognitive framework: Don't get left behind, don't get pushed to the side, you should be on the cutting-edge, if not, you will be left out and alone...

- Repetition of key words to facilitate memorization and highlight the most important ideas.

International level, investment, billing, customer

- Simplification of the product. The tendency towards simplification is anthropological. What is developed with simplicity sells better. Monotheistic religions, for example, triumphed because they simplified a complex plurality of gods. Only one god to worship is easier. Simplicity is much more practical and sells better, even if it is not better. 
the only thing that we have done

And we do it in the following way: simply communicating to the hotel..."

It is very easy

- Direct appeal to the customers,

If you were considering booking a reservation in any city and you were arriving in the city at 8 in the morning, you would not find any tool online that would permit you to check into the hotel at that time. "You would have to check in at twelve, at one, at two in the afternoon...": They put the customer in a real-life situation, they visualize the problem, they put it in front of their eyes. The rhetorical questions are similar:

You will have to check in at twelve, at one, at two in the afternoon. Why? Because the hotel does not have any tool that would permit it to really adapt to this operational procedure.

\subsection{Actio}

In this section, the communicative ability of the individual comes into play (ethos): informal attire, characteristic of a young entrepreneur; non-verbal communication (modulating the voice, gestures to show confidence, aplomb). Passion is ethos, information, logos.

\section{Analysis and Results of a Negative Model of Discourse}

In any case, while it is true that the discourse of ByHours.com allows us to confirm the potential of persuasion that speech in the workplace can have if it follows the rules precisely and is supported by the appropriate ethos, it is also true that other discourses following the same program, based on the same model, do not achieve the same communicative success. This is due to a lack of ethos, to deficiencies in oral dexterity or to an absence of discipline in following the rules that should be observed in the elaboration of persuasive discourse.

In the next example, Vertical Ecosystem presents a type of plant cover for buildings to create natural insulation. If the discourse of ByHours is a canonical discourse of what an Elevator Pitch should be, Vertical Ecosystem (http://www.rtve.es/alacarta/videos/tu-oportunidad/tu-oportunidad-

verdtical/2158494/) is a canonical example of what an Elevator Pitch and persuasive speech should not be. Supposedly, the speaker of the following fragment has been trained, knows what to do, has precise instructions, has models, etc. but the result, as the interviewers on the program well note, is disorganization and chaos. The speaker does not follow the model of discourse; something which becomes more and more obvious in the remarks made as the discourse unfolds.

\footnotetext{
- B.- What problems do you solve? Tell us.

$-\quad \ldots$

- $\quad$ B.- The benefit for everyone else I understand very well...

$-\quad \ldots$

- $\quad$ C.- Do you have some other sample...

- $\quad$...

- C.-Tell us a little about yourselves, your company, partners, how long you have been working in the company, what the company turnover is...
} 
- D.- And what are your profits from this, what margins do you have, what cost structure?

- $\quad \ldots$

- B.- To get to that $50 \%$ profit, how many people are you?

$-\quad \cdots$

- C.- Can you, can you tell me how much you have invested until now or how much have you and your father invested and what is the percentage each of you has in the partnership?

- $\quad$...

- F.- I am not seeing a business. Until now I am seeing a vertical garden, which is nothing new, there are in other... in Japan....

- $\quad \ldots$

- $\quad$ C.- No, what you need is to convince the rest because we have to get to 100,000. You have to sell yourself.

$-\quad \cdots$

- $\quad$ D.- With this product, the room for development is huge, the problem is the amount of disorganization...

- $\quad$...

- D.- To me the product sounds amazing, really, and the rest of it is a mess...

It is these remarks, these indications, and this request for information that the speaker will have to cope with. What the interlocutors are asking for is nothing less than the essence of the Elevator Pitch. A discourse should be well-organized, provide information, novelty, solve problems. The speaker should be developing the argument technically, separating things into smaller chunks, enveloping the interlocutor, adding arguments, giving responses, selecting the most positive lexis and adding up the benefits. All of this should be done with passion. In other words, neither inventio, nor dispositio nor elocutio nor actio were developed in the expected way. The questions the interlocutors asked are key to understand what contents a discourse of these characteristics should have. Furthermore, from my point of view, it is important to know how one should argue in favor of something keeping in mind what the investors value, since, in theory, what the format of the Elevator Pitch is already known.

Practically, all the investors' questions go in one direction. In almost all the discourses studied, they ask the companies for the same financial information:

- Business plan

- Objectives

- Company value

- Capital

- Initial investment

- Partners and percentages of ownership of the business

- Price, profit, margins

- Current and expected income

- Workforce numbers

- Public goals and development areas

Nevertheless, they also have other questions:

- Testing, seeing the product and understanding it.

- What would make me decide to buy it?

- What problems need to be resolved?

- To convince, explain the novelty, profits and differences 
- Information about the entrepreneur: "Tell me about you, your education, your background, what professional experiences you have had, your strengths, your weaknesses, how well you know how to sell, how much effort you are going to put into the project?

Errors are found in almost all parts of the presentation of the Vertical Ecosystem, in ethos, pathos and logos. Looking at content alone, the weakness is evident. The theory should be clear, but the staging and the words fail.

The positive lexis supporting the main discursive ideas is practically zero. Constant repetitions occur and mark an intermittent discourse with jumps in the argumentation (i.e., anacoluthon):

- ... This is a living portrait but what really but really what Vertical is a manufacturer of vertical ecosystems. What we do really is systems capable of providing nature to the structure itself.

- Through what is the material, which now I will tell you about, material from chemistry that we have developed, our own way; it is an ultralight material, which allows making these types of structures, which don't weigh a lot and which you install yourself as you can see from this graph.

So, more than well-structured piece with a concrete outline, there is an erratic conversation with constant overlapping, lacking coherence, order and technique.

Except for the introduction, the rest is chaos.

\section{Conclusion}

The rhetorical analysis of the speeches presented allows us to observe from their planning (inventio) to their staging (actio) the persuasive communication strategies that demonstrate their effectiveness. Thus, in the first case, courtesy is a fundamental element in the elocution of the discourse, a courtesy that seeks an emotional response of reciprocity. The structure of the discourse (dispositio) is perfectly ordered (name, objective, presentation of the product...) and provides the greatest argumentative weight in question time. In the linguistic formulation (elocutio) it selects the most suitable terms to be interpreted in cognitive frameworks favourable to the sender (technicalities to give authority to the discourse, positive terms, arguments of authority, arguments of novelty) and a staging in accordance with the image of an entrepreneur (non-verbal communication). In contrast, the second case does not respect any of the conventions that lead to success in the first discourse and lead to failure in its presentation.

In short, knowledge of the cognitive processes produced in the interpretation of the message (O'Keefe, 2011; Petty and Cacioppo, 1996; Shermer, 2011) is fundamental to create an ad hoc message that can achieve success in communication.

\section{References}

Albadalejo, Tomás. 2014. Rhetoric and Discourse Analysis. In Inés Olza, Óscar Loureda and Manuel Casado-Velarde, eds., Language Use in the Public Sphere, Bern, Peter Lang, 19-52.

Aristóteles. 2000. Retórica, Madrid, Gredos.

Brown, Penelope and Stephen Levinson. 1987. Politeness: Some Universals in Language Usage, Cambridge, Cambridge University Press. 
Carnegie, Dale. 1994. Cómo hablar bien en público, Barcelona, Edhasa. [Dale Carnagey (Carnegie) and J. Berg Esenwein. 1915. The Art of Public Speaking. New York Public Library. Home Correspondence School.]

Eible-Eibesfeldt, Irenaus. 1993. Biología del comportamiento humano, Madrid, Alianza Editorial.

Escandell, Victoria; Ahern, Aoife; Amenós, José. 2020. Pragmática, Madrid, Akal (in press).

Fernández, Eduardo. 2006. Retórica clásica y publicidad, Logroño, Instituto de Estudios Riojanos.

Greenwald, Anthony. 1968. Cognitive Learning, Cognitive Response to Persuasion, and Attitude Change. In Anthony Greenwald, T. C. Brock, and T. M. Ostrom, eds., Psychological Foundations of Attitudes, New York, Academic Press, 147-170.

Laborda Gil, Xavier. 1996. Retórica interpersonal, Barcelona, Octaedro.

Laborda Gil, Xavier. 2014. La inteligencia comunicacional, Barcelona, Plataforma Editorial.

Lafuente, Enrique, et al. 2017. Historia de la Psicología, Madrid, UNED.

Lakoff, George. 1996. Moral Politics, University of Chicago Press.

Lakoff, George. 2004. Don't Think of an Elephant, Know Your Values, Frame the Debate, Chelsea Green Publishing.

Lakoff, Robin. 1973. The logic of Politeness: Or Minding your P's and Q's. In C. Corum, T. Cedric Smith-Stark and A. Weiser, eds., Proceedings of the Ninth Regional Meeting of the Chicago Linguistic Society, 292-305.

O' Keefe, Daniel. 2011. Generalizing about the Persuasive Effects of Message Variations: The Case of Gain-Framed and Loss-Framed Appeals. In Bending Opinion. Essays on Persuasion in the Public Domain. Rhetoric in Society. Leiden University Press, 117133.

Petty, Richard. E. y Cacioppo, John T. 1996. Communication and Persuasion. Central and Peripherical Routes to Attitude Change, New York, Springer Verlag.

Pujante, David .1999. El hijo de la persuasión. Quintiliano y el estatuto retórico, Logroño, Instituto de Estudios Riojanos.

Santiago-Guervós, Javier de. 2005. Principios de comunicación persuasiva, Madrid, Arco/Libros.

Santiago-Guervós, Javier de. 2008. Comentario de textos persuasivos, Madrid, Arco/Libros.

Shermer, Michael. 2011. The Believing Brain, New York, Times Books.

Wason, Peter C. 1960. On the Failure to Eliminate Hypotheses in a Conceptual Task. Quarterly Journal of Experimental Psychology (Psychology Press) 12 (3), 129-140.

Weber, Max. 1996. Economía y Sociedad, México City, Fondo de Cultura Económica. 